\title{
Paranasal Sinus Lymphoma
}

National Cancer Institute

\section{Source}

National Cancer Institute. Paranasal Sinus Lymphoma. NCI Thesaurus. Code C6068.

A lymphoma that arises from the paranasal sinus. Representative examples include

diffuse large B-cell lymphoma and extranodal NK/T-cell lymphoma, nasal type. 